\title{
Anestesia Spinal untuk Seksio Sesarea pada Pasien Hipotiroid
}

\author{
Rizqi Adhelia', Sri Rahardjo², Yusmein Uyun ${ }^{3}$ \\ ${ }^{1}$ Departemen Anestesi dan Terapi Intensif RSUD A Dadi Tjokrodipo, Bandar Lampung, ${ }^{2}$ Departemen Anestesi dan \\ Terapi Intensif Fakultas Kedokteran Universitas Gadjah Mada-RSUP Dr. Sardjito, Daerah Istimewa Yogyakarta
}

\begin{abstract}
Abstrak
Disfungsi tiroid sering dijumpai pada populasi perempuan usia masa reproduksi. Efek disfungsi tiroid bermanifestasi pada berbagai organ dan mungkin menimbulkan komplikasi pembedahan dan kehamilan. Seorang perempuan 37 tahun dengan hipotiroid akan menjalani seksio sesarea. Kadar tiroid timulating hormone (TSH): dan tiroksin (T4) adalah 14,87 $\mu \mathrm{UI} / \mathrm{mL}$ dan $71 \mathrm{nmol} / \mathrm{L}$. Pasien mendapat terapi levotiroksin selama 6 minggu. Pada pemeriksaan fisik, pasien dalam keadaan umum baik. Anestesia spinal dilakukan dengan bupivakain 0,5\% 7,5 mg dan fentanyl $25 \mu \mathrm{g}$. Bayi lahir dengan skor Apgar 8/9, hemodinamik stabil selama operasi. Pasien pulang dari rumah sakit setelah hari ke tiga operasi. Pasien hipotiroid dapat mengalami komplikasi koma miksedema, gangguan respirasi, maupun hipotensi selama pembedahan. Pembedahan elektif sebaiknya ditunda sampai kondisi eutiroid. Anestesia spinal dosis rendah, monitoring adekuat, pencegahan hipotermia, pengurangan opioid, dan terapi levotiroksin perioperatif dibutuhkan untuk mencegah komplikasi jika kondisi eutiroid belum tercapai. Sebagai kesimpulan anestesia spinal dapat dilakukan pada pasien hipotiroid yang menjalani seksio sesarea.
\end{abstract}

Kata kunci: anestesia spinal; hipotiroid; seksio sesarea

\section{Anesthesia for Cesarean Section in Hypothyroid Patient}

\begin{abstract}
Thyroid disfunction is common in woman of child-bearing age population. Multiple organ are influenced with thyroid dysfunction and may contribute to complication during surgery and pregnancy. A 37-years-old female with hypothyroid was scheduled for cesarean section. Thyroid stimulating hormone (TSH) and thyroxine (T4) level was $14,87 \mu \mathrm{UI} / \mathrm{mL}$ and $71 \mathrm{nmol} / \mathrm{L}$. The patient had levothyroxine therapy for 6 weeks. On physical examination, the general condition was good. She underwent spinal anesthesia with bupivacaine $0,5 \% 7,5 \mathrm{mg}$ and fentanyl 25 $\mu \mathrm{g}$. The baby was born with Apgar score 8/9 and the surgery was done without any complication. The patient was discharged from the hospital on the 3rd day after surgery. The hypothyroid patient may experience complication of myxedema comatous, respiratory disorder and hypotension during surgery. The elective surgery was best postponed until a euthyroid state was achieved. Low dose spinal anesthesia, adequate monitoring, hypothermia prevention, reducing opioid dose and continuing levothyroxine therapy was needed to prevent the complication if the euthyroid state was able not able to achieve. As conclusion : spinal anesthesia may be done for cesarean section in hypothyroid patient.
\end{abstract}

Key words: cesarean section; hypothyroid; spinal anesthesia 


\section{Pendahuluan}

Penyakit tiroid merupakan penyakit gangguan hormonal kedua terbanyak yang paling sering ditemui dalam periode perioperatif. Pasien dengan disfungsi tiroid sering dijumpai pada populasi terutama pada perempuan usia masa reproduksi. Angka prevalensi hipotiroid pada populasi yaitu $2 \%{ }^{1}$ Perbandingan perempuan dengan laki-laki yang memiliki penyakit tiroid adalah antara 5: 1 dan 10:1. Kelainan tiroid sering asimptomatik dan sulit dibedakan dengan penampilan perubahan fisiologis pada kehamilan. Hipotiroid dapat terjadi secara kongenital maupun sekunder akibat kerusakan kelenjar tiroid karena pembedahan, radang dan radiasi, kekurangan ion iodin atau penyakit pada kelenjar hipofisis.

Hipotiroid subklinis (kadar tinggi Thyroid Stimulating Hormone/TSH dengan normal free T4) terjadi pada $2-3 \%$ kehamilan dan prevalensi hipotiroksinemia isolated (Normal TSH dengan free $\mathrm{T} 4$ rendah) sekitar $2 \%$ pada kehamilan. ${ }^{2,3}$ Hipotiroid dapat menimbulkan masalah kesehatan utama selama periode kehamilan dan perianestesi. Pasien hipotiroid subklinis terkait dengan hiperkolesterolemia, aterosklerosis, keluaran obstetri buruk seperti aborsi, kelahiran prematur, gangguan fungsi kognisi pada bayi dan infertilitas, gejala neuropsikiatrik, mortalitas kardiovaskular, kolelitiasis. Efek hipotiroid pada sistem kardiovaskular dapat meliputi gangguan kontraktilitas kardial, peningkatan resistensi vaskular perifer, penurunan tekanan darah sistolik, peningkatan tekanan darah diastolik dan bradikardi. ${ }^{4-6}$

Komplikasi terberat pembedahan pada pasien dengan hipotiroid yaitu terjadinya koma miksedema, suatu kondisi dengan mortalitas $80 \%$, dengan karakteristik perubahan status mental, bradikardia, hiponatremia, gagal jantung dan hipopnea. Kejadian ini berkaitan dengan faktor pencetus seperti pembedahan, infeksi, paparan dingin dan pemberian sedatif. ${ }^{7}$ Dalam kasus ini dibahas mengenai manajemen anestesi pada pasien hipotiroid subklinis dan pencegahan komplikasi.

\section{Kasus}

Anamnesis/Riwayat Penyakit

Wanita 37 tahun (G3 P2 A0) dikonsulkan untuk menjalani seksio sesarea dan metode operatif wanita (MOW) atas indikasi presentasi bokong. Pasien menderita hipertiroid 7 tahun yang lalu, setelah kelahiran anak kedua. Pasien kemudian menjalani terapi radionuklir leher dan dikatakan hasil hormon tiroid normal. Pasien tidak pernah kontrol selanjutnya. Selama kehamilan terakhir pasien tidak mengeluhkan gejala-gejala kelelahan, tidak tahan dingin, konstipasi maupun berdebar, tidak tahan panas, atau penurunan berat badan.

\section{Pemeriksaan Fisik}

Keadaan umum compos mentis, berat badan 60 $\mathrm{kg}$, tinggi badan $155 \mathrm{~cm}$.

Tanda vital: tekanan darah 120/70 $\mathrm{mmHg}$, laju nadi $72 \mathrm{kali} / \mathrm{menit}$, laju nafas $20 \mathrm{kali} / \mathrm{menit}$, suhu $37^{\circ}$ Celcius.

Kepala: konjungtiva tidak anemis, sklera tidak ikterik, lidah tidak membesar, skor Mallampati II, tidak ada massa leher

Dada: suara paru vesikuler normal, suara jantung reguler

Abdomen: peristaltik normal, tinggi fundus uterus $30 \mathrm{~cm}$

Ekstremitas: edema pretibial positif kanan dan kiri.

\section{Pemeriksaan Penunjang}

Hasil pemeriksaan laboratorium ditampilkan dalam tabel 1. Pemeriksaan elektrokardiografi didapatkan normal sinus ritme.

Pasien dinilai sebagai status fisik ASA II dengan hipotiroid.

\section{Pengelolaan Anestesi}

Pasien dikonsulkan ke bagian penyakit dalam dan mendapatkan terapi levotiroksin oral 50 $\mu \mathrm{g}$ dalam 2 dosis pemberian selama 6 minggu. Setelah usia kehamilan 37 minggu dilakukan pemeriksaan kadar TSH ulang didapatkan nilai $11,7 \mu \mathrm{UI} / \mathrm{mL}$ (nilai rujukan normal $0,27-$ 4,2) dalam dalam kondisi klinis baik. Pasien dijadwalkan untuk dilakukan pembedahan. 
Tabel 1. Hasil Pemeriksaan Laboratorium

\begin{tabular}{llllll}
\hline Parameter (satuan) & Hasil & Nilai rujukan & Parameter $(\mathrm{satuan})$ & Hasil & Nilai rujukan \\
Hemoglobin $(\mathrm{g} \%)$ & 11,9 & $12-15$ & Kalsium $(\mathrm{mg} / \mathrm{dL})$ & 10,5 & $8,8-12$ \\
Leukosit $(\mu \mathrm{L})$ & 10,1 & $4,5-10,7$ ribu & T3(nmol/L) & 1,47 & $0,92-2,33$ \\
$\begin{array}{l}\text { Trombosit }(\mu \mathrm{L}) \\
\text { Waktu }\end{array}$ & 240.000 & $15-4004$ ribu & T4(nmol/L) & 71,26 & $71-142$ \\
perdarahan(menit) & 3 & $1-7$ & $\begin{array}{l}\text { TSH sebelum } \\
\text { terapi }(\mu \mathrm{IU} / \mathrm{mL})\end{array}$ & 14,87 & $0,25-5$ \\
$\begin{array}{l}\text { Waktu } \\
\text { pembekuan(menit) }\end{array}$ & 12 & $9-15$ & $\begin{array}{l}\text { TSH sesudah terapi } \\
(\mu \mathrm{IU} / \mathrm{mL})\end{array}$ & 11,75 & $0,27-4,2$ \\
$\begin{array}{l}\text { Gula darah } \\
\text { sewaktu }(\mathrm{mg} / \mathrm{dL})\end{array}$ & 102 & $70-200$ & Natrium $(\mu \mathrm{mol} / \mathrm{L})$ & 141 & $135-150$ \\
$\begin{array}{l}\text { Ureum }(\mathrm{mg} / \mathrm{dL}) \\
\text { Creatinin }(\mathrm{mg} / \mathrm{dL})\end{array}$ & 16 & $10-40$ & Kalium $(\mu \mathrm{mol} / \mathrm{L})$ & 3,6 & $3,6-5,5$ \\
\hline & 0,5 & $0,7-1,3$ & Klorida $(\mu \mathrm{mol} / \mathrm{L})$ & 100 & $98-110$ \\
\hline
\end{tabular}

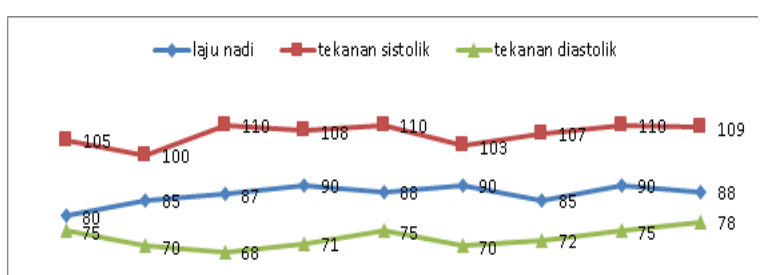

menit 0 menit 5 menit 10 menit 15 menit 20 menit 25 menit 30 menit 35 menit 40

Gambar 1. Grafik Hemodinamik selama Pembedahan

Monitoring di kamar operasi menggunakan alat pengukur tekanan darah non invasif, laju nadi, elektrokardiografi dan saturasi oksigen nadi. Akses pembuluh darah menggunakan jarum infus $18 \mathrm{G}$ dan dilakukan penggantian cairan selama puasa menggunakan cairan Ringer Laktat sebanyak $10 \mathrm{~mL} / \mathrm{kg}$. Dilakukan anestesi spinal pada posisi duduk menggunakan jarum spinal Quincke no 27 pada level lumbal 4-5 dengan bupivakain 0,5\% 7,5 mg dengan fentanyl $25 \mu \mathrm{g}$. Pasien diposisikan supine setelahnya dan level ketinggian blok sensorik mencapai dermatom torakal 6 . Tidak terjadi penurunan hemodinamik setelah anestesi spinal. Bayi lahir dengan skor APGAR 8/9. Operasi berlangsung selama sekitar 40 menit dengan hemodinamik stabil (ditampilkan pada gambar 1), dengan jumlah perdarahan sekitar $800 \mathrm{~mL}$.

\section{Pengelolaan Pascabedah}

Pasien dimonitor di ruang pemulihan setelah pembedahan selesai. Obat pengurang nyeri setelah operasi diberikan parasetamol 1000 mg setiap 6 jam dan ketorolak $30 \mathrm{mg}$ injeksi intravena setiap 8 jam pada hari pertama, dilanjutkan ketoprofen oral $100 \mathrm{mg}$ setiap 8 jam. Terapi levotiroksin dilanjutkan setelah operasi dan pasien dipulangkan pada hari ke tiga setelah operasi dalam kondisi baik. Tidak terjadi komplikasi pernafasan, kardiovaskular maupun konstipasi selama perawatan.

\section{Pembahasan}

Hormon tiroid memegang peranan penting sistemik karena efek pada kardiovaskular, respirasi, renal, gastrointestinal, hematologis dan sistem syaraf pusat. Hipotiroid adalah kondisi dimana kelenjar tiroid tidak dapat memproduksi hormon tiroid sesuai dengan kebutuhan tubuh. Penyebab hipotiroid yaitu faktor endogen seperti kekurangan ion iodin, kerusakan kelenjar tiroid karena tiroiditis, dan faktor eksogen seperti tiroidektomi, ablasi tiroid karena radioaktif iodin, eksternal irradiasi. Hipotiroid subklinis ditandai dengan peningkatan kadar serum TSH pada individu dengan penampakan sehat. ${ }^{7}$ Gejala hipotiroid sering menyerupai perubahan fisiologis kehamilan seperti merasa lelah, tidak tahan terhadap dingin, konstipasi, kram otot, insomnia, penambahan berat badan, sindroma carpal tunnel, kehilangan rambut, 
perubahan suara dan perlambatan berpikir. Tanda lain dapat berupa kulit kering, edema peri-orbital dan penurunan refleks tendon atau pembesaran kelenjar tiroid karena peningkatan vaskularitas dan hiperplasia. Wanita dengan hipotiroid menunjukkan penurunan fertilitas karena disfungsi ovarium dan neuroendokrin serta sering terjadi aborsi. Risiko komplikasi kehamilan seperti anemia, hipertensi gestasional, solusio plasenta, kelahiran prematur dan perdarahan sesudah melahirkan. ${ }^{6,8,9}$ Masih terjadi perdebatan mengenai perlunya pemeriksaan fungsi tiroid pada wanita hamil, namun dengan mempertimbangkan risiko komplikasi maka perlu dipertimbangkan perlunya pemeriksaan fungsi tiroid. Hal ini terutama pada wanita hamil dengan riwayat penyakit tiroid, riwayat keluarga dengan penyakit tiroid, memiliki penyakit autoimun, adanya goiter, riwayat radiasi leher sebelumnya, riwayat pengobatan yang mengganggu tiroid seperti interferon dan lithium. ${ }^{10}$

Pada kasus ini tidak ditemukan tanda-tanda khas hipotiroid tetapi terdapat riwayat penyakit hipertiroid dan radiasi leher sebelumnya. Sehingga pemeriksaan fungsi tiroid penting dilakukan pada pasien ini. Komplikasi hipotiroid pada kehamilan tidak terjadi pada kasus ini. Pasien dengan hipotiroid memiliki peningkatan risiko kejadian penyakit arteri koroner disebabkan karenapeningkatan kadarkolesterol, pemanjangan waktu paruh faktor-faktor koagulasi dan anemia. Perubahan segmen ST non spesifik dan elektrokardiogram low voltage sering dijumpai, dan lebih jarang terjadinya torsade de pointes dan ventrikular takikardi. Hipotiroid dikaitkan dengan penurunan keluaran kardiak 30-50\% dengan perlambatan denyut nadi dan kontraktilitas. Lebih lanjut, defisiensi hormon tiroid menyebabkan peningkatan resistensi pembuluh darah perifer sehingga terjadi peningkatan tekanan darah diastolik dan penurunan tekanan darah sistolik. Meskipun kadar katekolamin meningkat, pasien dengan hipotiroid memiliki predisposisi untuk terjadi hipotensi setelah anestesi, kemungkinan karena down-regulation reseptor B-adrenergik. ${ }^{7}$ Pada pasien ini tidak didapatkan kelainan pada elektrokardiogram. Pasien dengan hipotiroid memiliki tantangan tambahan akibat disfungsi ventilasi dan manifestasi renal. Obstruksi langsung jalan nafas atas dapat terjadi karena ukuran lidah yang membesar dan obesitas yang sering timbul pada pasien hipotiroid. Efusi pleura dan kelemahan otot respirasi, bersamaan dengan kerusakan pusat pernafasan hiperkapnea dan hipoksia, peningkatan prevalensi obstructive sleep apnea merupakan predisposisi pneumonia dan atelektasis sehingga meningkatkan komplikasi perioperatif. ${ }^{7,8}$ Pembesaran lidah dan obesitas tidak terjadi dalam kasus ini. Anestesia regional dapat memberi keuntungan dengan tidak memberi intervensi terhadap respirasi, mengurangi pemberian obat-obat sedatif dan opioid, menghindari masalah sulit intubasi dan ekstubasi sesudah operatif.

Pasien dengan hipotiroid dapat bermanifestasi dengan hipoglikemia dan hiponatremia. ${ }^{7}$ Peningkatan antidiuretik hormon menyebabkan hiponatremia. Peningkatan permeabilitas kapiler dan pergeseran cairan ke ruang ekstravaskular menurunkan volume intravaskular dan perfusi renal menyebabkan penurunan klirens obat. Faktor-faktor renal dan respirasi tersebut berkontribusi terhadap peningkatan penerimaan pasien terhadap obat-obat anestesia, penenang dan narkotika. ${ }^{9}$ Hipotiroid terkait dengan efek hematologis yaitu anemia normositik, normokromik. Namun dapat juga muncul sebagai makrositosis jika bersamaan dengan autoimun defisiensi vitamin B12 atau mikrositik pada defisiensi besi. Manifestasi hematologis lainnya yaitu disfungsi trombosit, penurunan faktor VIII, pemanjangan waktu tromboplastin parsial dan penyakit Von Willebrand. ${ }^{6,9}$

Sehingga dalam pemilihan teknik anestesi regional, status koagulasi pasien harus diperhatikan. Jika terjadi suatu koagulopati, adanya risiko hematoma epidural, maka anestesia umum menjadi teknik anestesia pilihan. Dalam kasus ini, pasien tidak mengalami anemia, hipoglikemia, hiponatremia dan gangguan koagulasi sehingga dapat dipilih anestesia regional. Penurunan motilitas gastrointestinal pada umumnya bermanifestasi sebagai konstipasi dapat meningkatkan kecenderungan untuk terjadi ileus setelah pembedahan. Perlu dipertimbangkan 
keuntungan dan kerugian pemberian opioid dalam manajemen nyeri setelah pembedahan yang juga dapat menyebabkan konstipasi. ${ }^{7,9}$ Anestesia regional dengan anestesia lokal dosis rendah dengan penggantian volume intravaskular dapat menjadi pilihan yang tepat untuk pasien hipotiroid yang membutuhkan pembedahan atau pembedahan darurat sedangkan status eutiroid tidak dapat dipastikan. ${ }^{11}$ Meskipun pada pasien hipotiroid dapat terjadi gangguan fungsi trombosit, kejadian hematom epidural adalah jarang terjadi. Fungsi koagulasi normal harus dipastikan sebelum melakukan anestesi regional. Anestesi regional dengan kateter kontinyu seperti anestesia epidural dapat dipergunakan untuk manajemen nyeri setelah operasi pada pasien hipotiroid untuk mengurangi opioid dan efek sampingnya seperti konstipasi dan ileus setelah pembedahan.

Komplikasi terberat pembedahan pada pasien dengan hipotiroid yaitu terjadinya koma miksedema, suatu kondisi dengan mortalitas $80 \%$, dengan karakteristik perubahan status mental, bradikardia, hiponatremia, gagal jantung dan hipopnea. Kejadian ini berkaitan dengan faktor pencetus seperti pembedahan, infeksi, trauma, perdarahan, penghentian suplementasi tiroid, perdarahan saluran gastrointestinal, paparan dingin dan pemberian sedatif., ${ }^{7,13}$ Pencegahan hipotermia perioperatif memberi manfaat berupa penurunan risiko infeksi luka, iskemia miokard, koagulopati perioperatif, kejadian menggigil. ${ }^{14}$ Selama pembedahan dan setelahnya, pencegahan hipotermia dilakukan dengan pemberian cairan infus hangat dan pemasangan matras penghangat. Pasien tidak menerima obat-obat sedatif seperti midazolam selama pembedahan.

Perubahan fisiologis terkait hipotiroidisme pada umumnya membaik dengan penggantian hormon tiroid. Sehingga disarankan untuk menunda operasi elektif dengan penanganan adekuat hormon tiroid sampai tercapai eutiroidisme dengan pemberian levotiroksin $1,6 \mathrm{mcg} / \mathrm{kg} /$ hari sampai didapat kadar TSH normal. Pada operasi darurat, pertimbangkan risiko penundaan operasi dibandingkan dengan komplikasi operasi. Pembedahan darurat atau penting dapat dilakukan dalam kondisi hipotiroid ringan dan sedang. Levotiroksin harus sudah diberikan preoperatif..,15 Pemberian hormon tiroid dengan cepat dapat mencetuskan infark miokardial, sehingga pasien dengan penyakit miokard iskemia harus mendapatkan pengawasan. ${ }^{16}$ Pada kasus pembedahan elektif seperti pada kasus ini, levotiroksin diberikan sebelum pembedahan, kemudian dilakukan evaluasi respon terapi dan fungsi tiroid ulang. Dengan adanya penurunan kadar TSH, kondisi klinis yang stabil diputuskan dilakukan pembedahan dengan melanjutkan pemberian levotiroksin perioperatif.

Suatu studi perbandingan keluaran setelah operatif pada pasien hipotiroid subklinis dengan pasien eutiroid yang menjalani coronary artery bypass grafting, tidak terdapat kejadian tidak diinginkan terhadap kardiovaskular yang bermakna, masalah penyembuhan luka, mediastinitis, infeksi ekstremitas bawah, komplikasi pernafasan, delirium atau operasi ulang dalam periode rawat yang sama. Akan tetapi didapatkan peningkatan kejadian atrial fibrilasi setelah operasi pada kelompok hipotiroid subklinis. ${ }^{7,14,15}$ Kadar tiroksin lebih dari $1 \mu \mathrm{g} / \mathrm{dL}$, tidak didapatkan bukti perlunya penundaan operasi. ${ }^{7}$ Hipotensi intraoperatif lebih sering terjadi pada kelompok hipotiroid. Untuk pembedahan kardiak, kolompok hipotiroid lebih sering mengalami kejadian gagal jantung, komplikasi gastrointestinal dan neuropsikiatrik. Hipotiroid berat meliputi pasien dengan koma miksedema atau komplikasi berat seperti perubahan mental, efusi perikardial atau gagal jantung, dan kadar tiroksin sangat rendah $(<1 \mu \mathrm{g} / \mathrm{dL})$. Jika pembedahan darurat diperlukan, levotiroksin intravena diberikan dosis awal 200 sampai $500 \mu \mathrm{g}$ diikuti 50 sampai $100 \mu \mathrm{g}$ per hari. Jika terjadi kecurigaan insufisiensi adrenal, diberikan glukotiroid sebelum atau bersamaan dengan hormon tiroid. ${ }^{?}$

Efek kardiovaskular yang sering terjadi setelah anestesia adalah hipotensi. Pemilihan teknik anestesia spinal dengan dosis bupivakain kecil diharapkan dapat mengurangi kejadian hipotensi setelah anestesi. Dalam suatu laporan kasus, anestesia spinal dosis kecil bupivakain 0,5\% $10 \mathrm{mg}$ merupakan metode yang aman untuk 
pembedahan darurat pasien dengan hipotiroid yang tidak dapat ditunda untuk mencapai kondisi eutiroid. ${ }^{11}$ Penggunaan bupivacain 0,5\% 7,5 mg dan fentanyl $25 \mathrm{mcg}$ untuk pembedahan seksio sesarea dalam penelitian-penelitian menimbulkan efek hemodinamik stabil dengan durasi analgesia yang lebih lama dibandingkan penggunaan bupivakain saja. ${ }^{17}$ Teknik anestesi epidural lebih baik dalam hal stabilitas hemodinamik dan pemanfaatan untuk manajemen nyeri setelah operasi. Teknik anestesia spinal umumnya lebih dipilih dalam segi biaya dan kemudahan.

\section{Simpulan}

Teknik anestesia spinal dapat dipilih untuk seksio sesarea pada pasien dengan hipotiroid. Beberapa strategi perlu dilakukan untuk mencegah komplikasi setelah anestesi dan pembedahan pada pasien hipotiroid.

\section{Daftar Pustaka}

1. Taylor PN, Zouras S, Min T, Nagarahaj K, Lazarus JH, Okosieme O. Thyroid screening in early pregnancy: pros and con. Frontiers in Endocrinology. 2018; 9: 1-7.

2. T Korevaar GE, Medici M, Visser TJ, Peeters RP. Tyroid disease in pregnancy: new insights in diagnosis and clinical management. Nat Rev Endocrinol. 2017; 13: 610-22.

3. Krassas GE, Poppe K, Glinoer D. Tyroid function and human reproductive health. Endocr Rev 2010; 31: 702-55.

4. Sannaboraiah SK, Ramaswamy AH, Shaikh S. Thyroid disorders during pregnancy and anesthetic considerations. Anaesth Pain \& Intensive Care. 2014;18(3):302-307.

5. Velasco, Taylor P. Identifying and treating subclinical tyroid dysfunction in pregnancy: emerging controversies. Eur J Endocrinol. 2018; 178: 01-12.

6. Korevaar TI, Schalekamp-Timmermans S, de
Rijke YB, Visser WE, Visser W, de Muinck Keizer-Schrama SM, et al. Hypotyroxinemia and TPO-antibody positivity are risk factors for premature delivery: the generation R study. J Clin Endocrinol Metab. 2013; 98: 4382-90.

7. HussainZ,ElahiS.Undetectedhypothyroidism and its anesthetic implications. Anaesth Pain \& Intensive Care. 2012; 16(2): 205-10

8. Chaker L, Bianco AC, Jonklaas J, Peeters RP. Hypotyroidism. Lancet 2017; 390: 1550-62.

9. Palace MR. Perioperative management of thyroid dysfunction. Health Service Insight 1-5. Available: https://us.segepub.com/enus/nam/open-access-at-sage

10. De Groot L, Abalovich M, Alexander EK, Amino N, Barbour L, Cobin RH, et al. Management of tyroid dysfunction during pregnancy and postpartum: an endocrine society clinical practice guideline. J Clin Endocrinol Metab. 2012; 97: 2543-65.

11. Buyukerkmen E, Ozturk S. Anaesthetic approach in a case with hypothyroiditis. Journal of Scientific Research and Report. 2017; 13(1): 1-4.

12. Dubbs SB, Spangler R. Hypothyroidism: causes, killers, and life-saving treatments. Emerg Med Clin North Am. 2014; 32: 303-17.

13. Gaitonde DY, Rowley KD, Sweeney LB. Hypothyroidism: an update. Am Fam Physician 2012; 14: 244-51

14. Sultan P, Habib AS, Cho Y, Carvalho B. The effect of patient warming during cesarean delivery on maternal and neonatal outcomes: a meta-analysis, Br. J of Anaesth, 2015: 115(4): 500-10

15. Keely E, Casey BM. Thyroid diseases in pregnancy. in Powrie RO, Greene MF, Camann W (eds). De swiet's medical disorders in obstetric practice. 5th ed. Chicester. Wiley-Blackwell; 2010, 322-32. 
16. Cignini $\mathrm{P}, \mathrm{CafàEV}$, Giorlandino C,Capriglione S, Spata A, Dugo N. Thyroid physiology and common diseases in pregnancy: Review of literature. J Prenat Med 2012; 6: 64-71.

17. Venkata HG, Pasupuleti S, Pabba UG, Porika S, Talari G. A randomized controlled prospective study comparing a low dose bupivacaine and fentanyl mixture to a conventional dose of hyperbaric bupivacaine for cesarean section. Saudi Journal of Anesthesia, 2015; 9 (2): 122-27. 